\title{
Slug suppression induces apoptosis via Puma transactivation in rheumatoid arthritis fibroblast-like synoviocytes treated with hydrogen peroxide
}

\author{
Hoon-Suk Cha', Eun-Kyung Bae ${ }^{2}$, \\ Joong Kyong Ahn ${ }^{1}$, Jaejoon Lee ${ }^{1}$, \\ Kwang-Sung Ahn ${ }^{3}$ and Eun-Mi Koh ${ }^{1,4}$

\section{'Department of Medicine} \\ Samsung Medical Center \\ ${ }^{2}$ Center for Molecular Medicine \\ Samsung Biomedical Research Institute \\ Sungkyunkwan University School of Medicine \\ Seoul 135-710, Korea \\ ${ }^{3}$ Department of Pathology \\ College of Medicine \\ Environmental Toxicogenomic and Proteomics Research Center \\ Korea University \\ Seoul 136-701, Korea \\ ${ }^{4}$ Corresponding author: Tel, 82-2-3410-3439; \\ Fax, 82-2-3410-3849; E-mail, emkoh@skku.edu \\ DOI 10.3858/emm.2010.42.6.044 \\ Accepted 23 April 2010 \\ Available Online 26 April 2010
}

Abbreviations: Ad-GFP, recombinant adenovirus expressing green fluorescent protein; Ad-p53, recombinant adenovirus expressing human wild-type $p 53$ gene; FLS, fibroblast-like synoviocytes; RA, rheumatoid arthritis; ST, synovial tissue; WCL, whole cell lysates

\begin{abstract}
Inadequate apoptosis contributes to synovial hyperplasia in rheumatoid arthritis (RA). Recent study shows that low expression of Puma might be partially responsible for the decreased apoptosis of fibroblast-like synoviocytes (FLS). Slug, a highly conserved zinc finger transcriptional repressor, is known to antagonize apoptosis of hematopoietic progenitor cells by repressing Puma transactivation. In this study, we examined the expression and function of Slug in RA FLS. Slug mRNA expression was measured in the synovial tissue (ST) and FLS obtained from RA and osteoarthritis patients. Slug and Puma mRNA expression in FLS by apoptotic stimuli were measured by real-time PCR analysis. FLS were transfected with control siRNA or Slug siRNA. Apoptosis was quantified by trypan blue exclusion, DNA fragmentation and caspase-3
\end{abstract}

assay. RA ST expressed higher level of Slug mRNA compared with osteoarthritis ST. Slug was significantly induced by hydrogen peroxide $\left(\mathrm{H}_{2} \mathrm{O}_{2}\right)$ but not by exogenous $\mathrm{p} 53$ in RA FLS. Puma induction by $\mathrm{H}_{2} \mathrm{O}_{2}$ stimulation was significantly higher in Slug siRNA-transfected FLS compared with control siRNA-transfected FLS. After $\mathrm{H}_{2} \mathrm{O}_{2}$ stimulation, viable cell number was significantly lower in Slug siRNA-transfected FLS compared with control siRNA-transfected FLS. Apoptosis enhancing effect of Slug siRNA was further confirmed by ELISA that detects cytoplasmic histone-associated DNA fragments and caspase- 3 assay. These data demonstrate that Slug is overexpressed in RA ST and that suppression of Slug gene facilitates apoptosis of FLS by increasing Puma transactivation. Slug may therefore represent a potential therapeutic target in RA.

Keywords: apoptosis; Puma; rheumatoid arthritis; snail family transcription factors; synovial membrane

\section{Introduction}

Rheumatoid arthritis (RA) is a chronic joint disorder characterized by inflammation and proliferation of synovial tissue (ST) resulting in bone and cartilage destruction. Hyperplasia of the synovial intimal lining results from marked increase in macrophage-like and fibroblast-like synoviocytes (FLS) (Firestein, 2003). One explanation for the synovial proliferation is an imbalance between cell proliferation and apoptosis or programmed cell death. The amount of DNA fragmentation is significantly increased in rheumatoid synovium (Firestein et al., 1995; Nakajima et al., 1995), which is presumably due to the oxidative stress generated by chronic inflammation (Tak et al., 2000). However, only low numbers of apoptotic cells are present in rheumatoid synovium (Nakajima et al., 1995; Matsumoto et al., 1996; Sugiyama et al., 1996; Ceponis et al., 1999), which suggests the discrepancy between apoptotic stimuli and real apoptotic cell death occurring in RA synovium. Therefore, impaired apoptosis may play an important role in the pathogenesis of RA.

Slug, which belongs to highly conserved Slug/Snail 
A
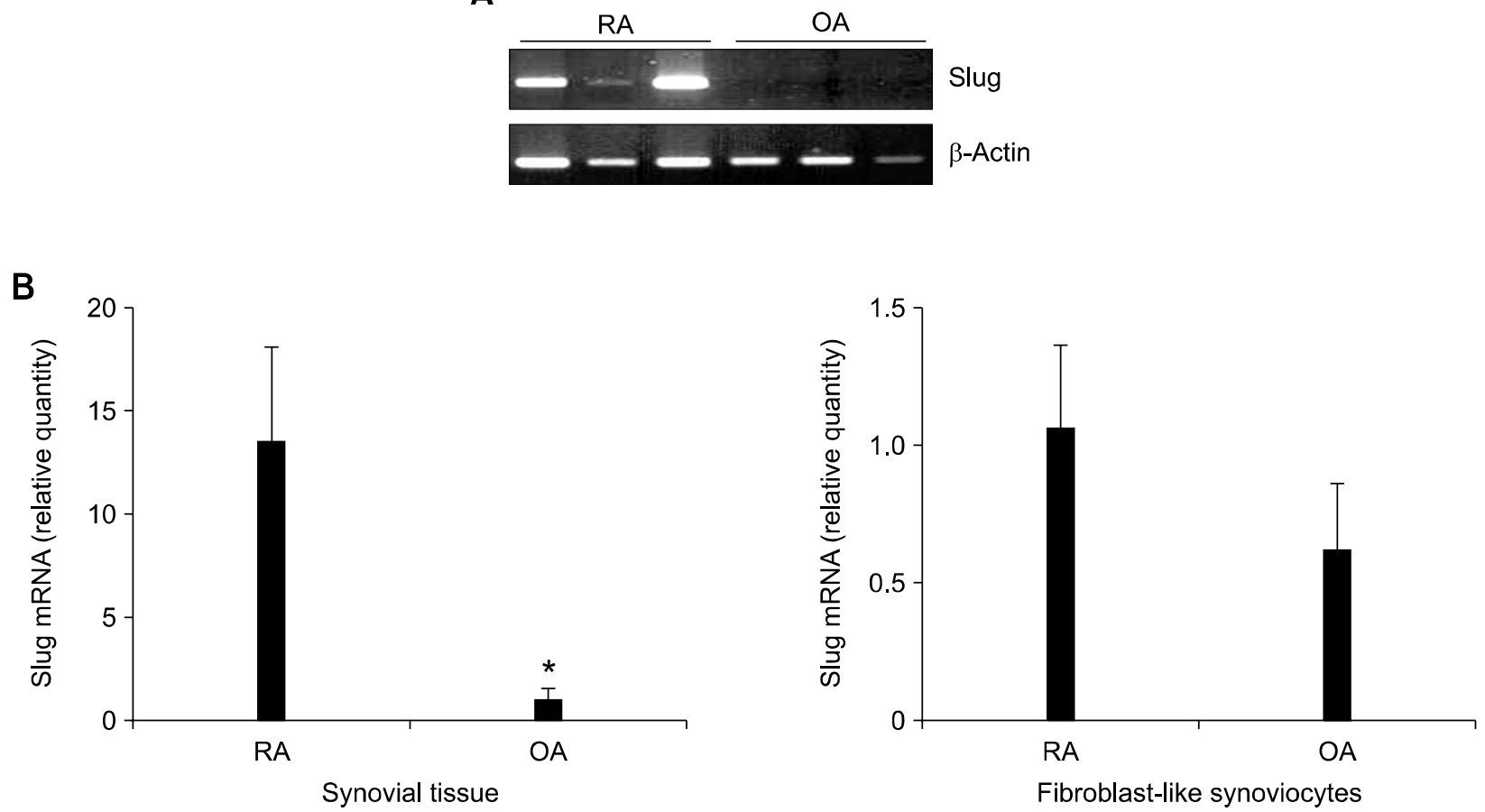

Figure 1. Slug is overexpressed in RA ST. (A) Total RNA was extracted from RA $(n=3)$ and osteoarthritis $(\mathrm{OA})(n=3)$ ST, and RT-PCR was performed to detect Slug mRNA expression. (B) Quantitative real-time PCR analysis was performed to quantify Slug mRNA expression in RA and osteoarthritis ST ( $n=$ 6 each) and FLS ( $n=3$ each). Data are mRNA level normalized to $\beta$-actin expression and shown as relative cell equivalents. ${ }^{*} P<0.005$ compared with RAST.

family, is a zinc finger transcriptional repressor. Slug/Snail protein family was found in diverse species from $C$. elegans to humans. In vertebrates, Snail and Slug transcription factors have been proposed to participate in mesoderm formation and neural crest cell migration (Hemavathy et al., 2000). These proteins have also been implicated in carcinogenesis, invasiveness and metastasis in various cancers including ovarian cancer, breast cancer and melanoma (Gupta et al., 2005; Kurrey et al., 2005; Martin et al., 2005; Perez-Mancera et al., 2005). Hematopoietic stem cells are resistant to ionizing radiation-induced apoptosis. Wu et al. demonstrated that Slug is transcriptionally induced by p53 upon irradiation and then protects the damaged hematopoietic progenitor cells from apoptosis by directly repressing p53-mediated transcription of Puma (Wu et al., 2005).

Puma is a $\mathrm{Bcl}-2$ homology $3(\mathrm{BH} 3)$-only proapoptotic Bcl-2 family member and mediates p53-dependent and -independent apoptosis (Han et al., 2001; Nakano and Vousden, 2001; Yu et al., 2001, 2003). The interaction of Puma with anti-apoptotic $\mathrm{Bcl}-2$ protein family members such as Bcl-xL induces mitochondrial dysfunction through Bax (Han et al., 2001; Nakano and Vousden, 2001; Yu et al., 2001). Puma is detected in both RA and osteoarthritis ST, but interestingly, its expression is low in RA synovial intimal lining, which is a major site of apoptotic stimuli and p53 expression. Exogenous p53 overexpression induced p21, but not Puma in FLS and this was associated with resistance of FLS to apoptosis. However, transfection of plasmid encoding Puma expression vector lead to rapid and profound apoptosis with caspase-3 activation in RA FLS (Cha et al., 2006). Tissue- and cell type-specific selectivity of p53 in transactivation of downstream genes has been reported (Fei et al., 2002). However, the mechanism in which p53 overexpression does not lead to Puma induction or apoptosis in FLS is unknown. Slug, which has been reported to repress Puma gene transcription in hematopoietic progenitor cells, might play a role in the down-regulation of Puma and impaired apoptosis of RA FLS. In this study, we investigated the expression and function of Slug in ST and cultured FLS in order to evaluate a potential strategy to induce apoptosis in synoviocytes. We now demonstrate that Slug gene is overexpressed in RA ST and that suppression of Slug facilitates apoptosis of RA FLS by increasing Puma gene expression. 
A

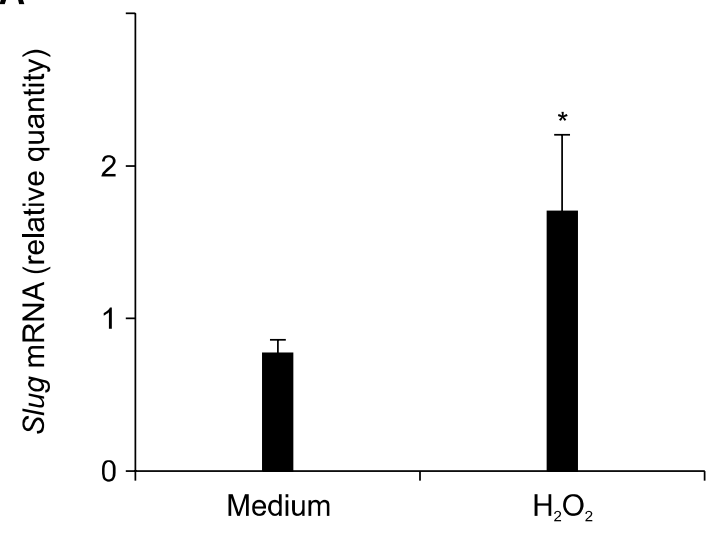

C

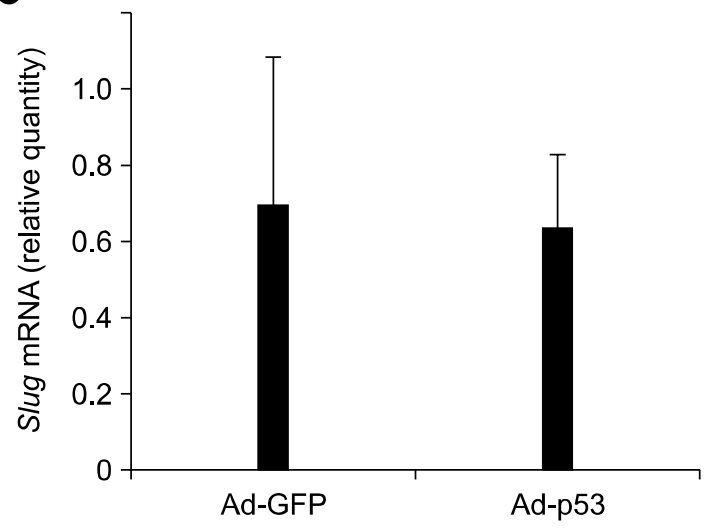

B
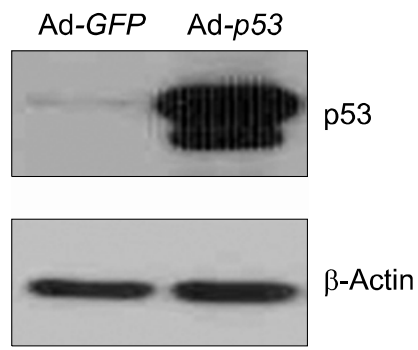

Figure 2. Slug is induced by $\mathrm{H}_{2} \mathrm{O}_{2}$ but not by p53 in RA FLS. (A) Total RNA was isolated from RA FLS $(n=3)$ after $6 \mathrm{~h}$ of medium or $\mathrm{H}_{2} \mathrm{O}_{2}(1 \mathrm{mM})$ treatment and quantitative real-time PCR was performed to measure Slug mRNA expression. Data are mRNA level normalized to $\beta$-actin expression and shown as relative cell equivalents. ${ }^{*} P<0.05$ compared with medium-treated cells. (B) Ad-p53 or Ad-GFP was infected to RA FLS for $24 \mathrm{~h}$. The overexpression of p53 protein in Ad-p53-infected FLS was confirmed by Western blot analysis (representative blot). (C) RA FLS $(n=6)$ were infected with Ad-p53 or Ad-GFP for $24 \mathrm{~h}$, and quantitative real-time PCR was performed to measure Slug mRNA expression.

\section{Results}

\section{Slug expression in RA ST and FLS}

Initially, we performed studies to determine whether Slug is expressed in RA ST and FLS. As shown in Figure 1A, Slug mRNA was detected in RA ST but not in osteoarthritis ST on gel PCR ( $n=3$ each). Quantitative real-time PCR also showed significantly elevated Slug mRNA level in RA ST compared to osteoarthritis ST ( $n=6$ each, $P<0.005$ ) (Figure 1B). Slug mRNA was also detected in FLS with a tendency of increased expression in RA FLS compared to osteoarthritis FLS ( $n=3$ each), but did not reach statistical significance $(P>0.10)$ (Figure 1B).

Next, we tried to examine whether apoptotic stimuli could induce Slug gene expression. Exposure of RA FLS to $1 \mathrm{mM} \mathrm{H} \mathrm{H}_{2} \mathrm{O}_{2}$ for $6 \mathrm{~h}$ resulted in significant increase of Slug mRNA $(n=3,3.0 \pm 0.8$ fold induction, $P<0.05$ ) (Figure $2 A$ ). To see the effect of p53 on Slug expression in FLS, Ad-p53 or Ad-GFP were infected for $24 \mathrm{~h}$ in RA FLS and marked increase in p53 protein expression in
Ad-p53-infected FLS was confirmed on Western blot analysis (Figure 2B). However, as shown in Figure 2C, Ad-p53-infected FLS showed no increase of Slug mRNA compared to Ad-GFP-infected FLS $(n=6, P>0.10)$.

\section{Effect of Slug suppression on Puma expression in RA FLS}

Because Slug is known as a transcriptional repressor of Puma, we next investigated the effect of Slug suppression on Puma expression in RA FLS. RA FLS were transfected with control or Slug siRNA for 3 days and the knocked-down effect was confirmed by RT-PCR (Figure $3 \mathrm{~A}$ ). $\mathrm{H}_{2} \mathrm{O}_{2}$ stimulation (1 $\mathrm{mM}$ for $6 \mathrm{~h}$ ) did not significantly increase Puma expression in control siRNA-transfected FLS $(n=3,1.6 \pm 0.2$ fold increase, $P>0.10)$. However, in Slug siRNA-transfected FLS, $\mathrm{H}_{2} \mathrm{O}_{2}$ stimulation significantly induced Puma mRNA expression on quantitative real-time PCR experiments $(n=3,4.7$ \pm 1.6 fold increase, $P<0.05$ )(Figure $3 \mathrm{~B}$ ). Without $\mathrm{H}_{2} \mathrm{O}_{2}$ treatment, increase of Puma mRNA by Slug 
A
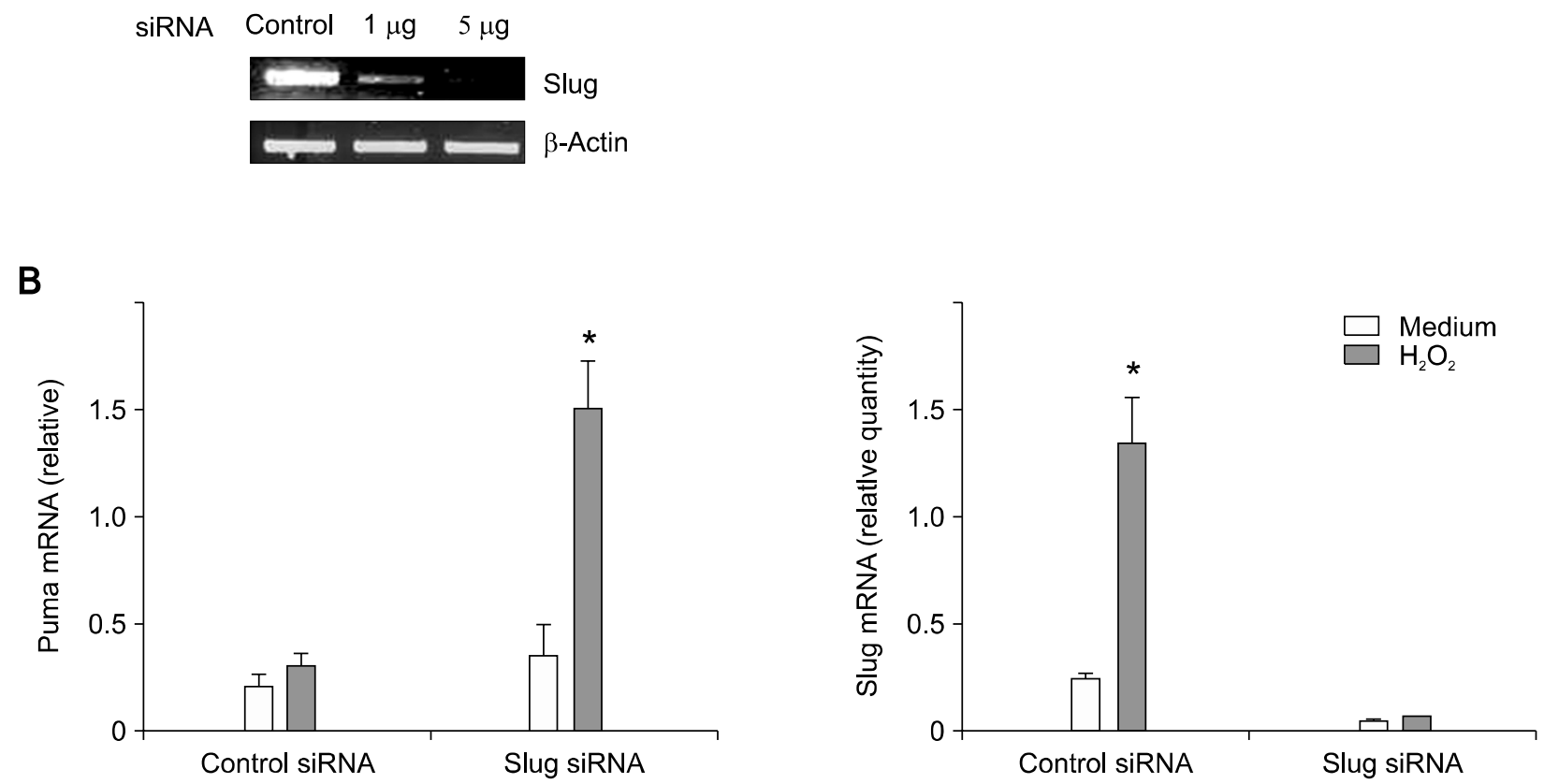

Figure 3. Slug knockdown increases $\mathrm{H}_{2} \mathrm{O}_{2}$-induced Puma expression in RA FLS. (A) Cultured FLS were transfected with 1 or $5 \mu \mathrm{g}$ of Slug siRNA or scrambled nonsilence control siRNA as described in Methods. FLS were then incubated for 3 days, and RT-PCR was performed. Maximum knockdown effect was observed with $5 \mu \mathrm{g}$ of Slug siRNA transfection. (B) RA FLS $(n=3)$ were transfected with $5 \mu \mathrm{g}$ of control or Slug siRNA for 3 days, and then treated with medium or $1 \mathrm{mM} \mathrm{H}_{2} \mathrm{O}_{2}$ for $6 \mathrm{~h}$. Total RNA was collected, and Puma mRNA was measured by quantitative real-time PCR. Slug mRNA level was measured in the same RNA samples using quantitative real-time PCR. Note the Slug suppression effect of Slug siRNA in both medium and $\mathrm{H}_{2} \mathrm{O}_{2}$-treated cells. ${ }^{*} \mathrm{P}<0.05$ compared with medium-treated cells.

siRNA transfection was minimal. In the same samples, we could find that the effect of significant induction of Slug by $\mathrm{H}_{2} \mathrm{O}_{2}$ in control siRNA-transfected FLS disappeared in Slug siRNA-transfected FLS with suppressed expression of Slug mRNA irrespective of $\mathrm{H}_{2} \mathrm{O}_{2}$ stimulation (Figure $3 \mathrm{~B}$ ).

\section{Effect of Slug suppression on FLS apoptosis}

Because we found that Slug suppression increased Puma expression in RA FLS, we next tried to examine whether Slug suppression could induce apoptosis of RA FLS. RA FLS were transfected with control or Slug siRNA for 3 days and then stimulated with $0.5 \mathrm{mM} \mathrm{H}_{2} \mathrm{O}_{2}$ for $6 \mathrm{~h}$. Cell morphology was observed on phase-contrast microscopy. As shown in Figure 4A, dead cells, which are characterized by nonadherent round appearance, were abundant in Slug siRNA-transfected FLS compared to control siRNA-transfected FLS. We next evaluated the effect of Slug suppression on cell death using trypan blue exclusion $(n=4)$. Slug siRNA transfection resulted in significantly decreased viable cell number after $9 \mathrm{~h}$ of $0.5 \mathrm{mM} \mathrm{H} \mathrm{H}_{2}$ stimulation compared to control siRNA transfection $\left(6.9 \times 10^{4} \pm 2.6 \times 10^{4}\right.$ vs $11.1 \times 10^{4} \pm 3.1 \times$ $\left.10^{4}, P<0.05\right)$ (Figure 4B). Enhanced apoptosis of RA FLS by Slug suppression was confirmed by ELISA detecting fragmented DNA in cytoplasm. RA FLS transfected with Slug siRNA showed $6.7 \pm$ 2.1 fold induction of DNA fragmentation compared to $2.1 \pm 0.6$ fold induction of DNA fragmentation in control siRNA-transfected $\mathrm{FLS}$ by $\mathrm{H}_{2} \mathrm{O}_{2}(0.5 \mathrm{mM}$ for $6 \mathrm{~h})(n=5, P<0.05)$ (Figure $5 \mathrm{~A})$. To confirm the activation of apoptosis pathway by Slug suppression, caspase-3 activity was measured after treatment of $0.5 \mathrm{mM} \mathrm{H}_{2} \mathrm{O}_{2}$ for $6 \mathrm{~h}$ in Slug siRNA- and control siRNA-transfected FLS. As shown in Figure $5 \mathrm{~B}$, caspase- 3 activity in response to $\mathrm{H}_{2} \mathrm{O}_{2}$ treatment was significantly elevated in Slug siRNA-transfected FLS compared to control siRNA-transfected FLS $(n=3, P<0.05)$.

\section{Discussion}

Tumor-like proliferation of synoviocytes plays a key role in the progression of $\mathrm{RA}$, and inadequate apoptosis of FLS contributes to this process (Firestein, 2003). Therefore, facilitating apoptosis in these cells is a reasonable strategy in the treatment of RA. In this report, we demonstrated 
A

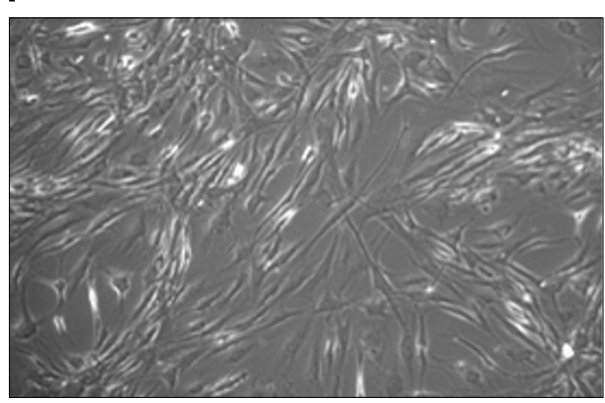

Control siRNA

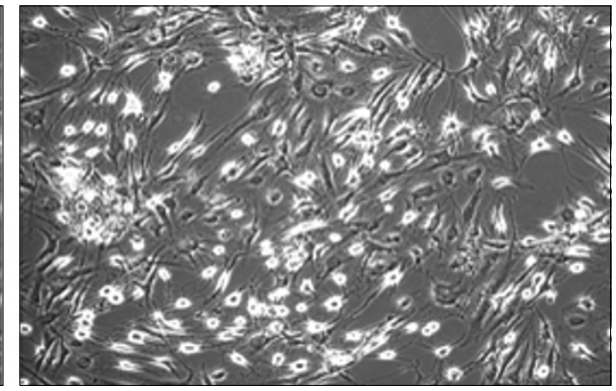

Slug siRNA

B

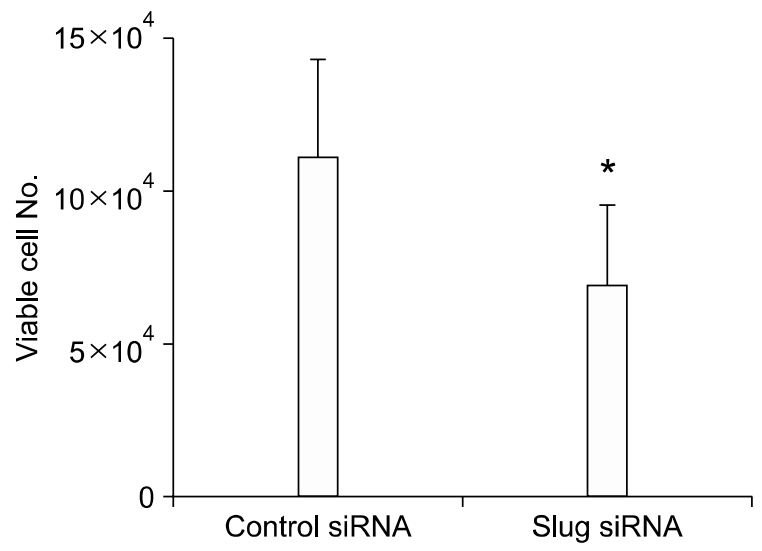

Figure 4. Slug knockdown facilitates $\mathrm{H}_{2} \mathrm{O}_{2}$-induced $\mathrm{FLS}$ death. (A) RA FLS were transfected with control or Slug siRNA for 3 days and then stimulated with $0.5 \mathrm{mM} \mathrm{H} \mathrm{O}_{2}$. After $6 \mathrm{~h}$, cell morphology was observed under phase-contrast microscopy (magnification $50 \times$ ). (B) RA FLS were transfected with control or Slug siRNA for 3 days and then treated with $0.5 \mathrm{mM} \mathrm{H}_{2} \mathrm{O}_{2}$. After $9 \mathrm{~h}$, viable cell number was counted by trypan blue exclusion as described in Methods. ${ }^{*} P<0.05$ compared with control siRNA-transfected cells.

for the first time that suppressing Slug could efficiently enhance apoptosis in RA FLS.

In the present study, Slug was detected in ST and FLS, and was transcriptionally more activated in RA ST compared to osteoarthritis ST. This result suggests that increased activation of Slug in RA synovium might contribute to impaired apoptosis. Slug was first identified as a transcription factor whose expression during embryonic development has been associated with mesoderm and migratory neural crest cells undergoing epithelial mesenchymal transformation (Hemavathy et al., 2000). Subsequently, evidence is accumulating that Slug regulates tumor carcinogenesis, metastasis and invasiveness in adult tissues. For example, Slug-overexpressing mice developed mesenchymal cancers, which were mainly leukemias (Perez-Mancera et al., 2005). Aberrant expression of Slug in breast adenocarcinomas protected against apoptosis induced by genotoxic stress and resulted in phenotypic alterations, including loss of cell adhesion and acquisition of invasive growth (Kajita et al., 2004). Induction of Slug by autocrine production of stem cell factor and c-Kit activation resulted in multidrug resistance in malignant mesothelioma cells (Catalano et al., 2004). Slug down-regulation by RNA interference facilitated apoptosis and inhibited invasive growth in neuroblastoma cells (Vitali et al., 2008). Slug is also known to be expressed and induced in nonmalignant cells such as keratinocytes by ultraviolet radiation (Hudson et al., 2007). Our study further demonstrated that Slug is inducible by genotoxic stimuli in RA FLS. Slug suppression by RNA interference markedly enhanced $\mathrm{H}_{2} \mathrm{O}_{2}$-induced apoptosis in RA FLS, and this was mediated by increased caspase- 3 activation. $\mathrm{H}_{2} \mathrm{O}_{2}$-induced cell necrosis could also have contributed to FLS death in our experiment (Byun et al., 2008), but obvious influence of Slug suppression on FLS apoptosis has been demonstrated by apoptosis specific ELISA and caspase- 3 activation assay. Because experiments comparing RA FLS with osteoarthritis FLS were not performed, we don't know whether these results are specific to RA FLS and it is unclear whether these Slug mediated apoptotic regulation is also operating in osteoarthritis or normal FLS. However, these results suggest that Slug plays an important role in the regulation of FLS apoptosis.

In response to DNA damage, the tumor suppressor p53 can either elicit apoptosis via Puma 
A

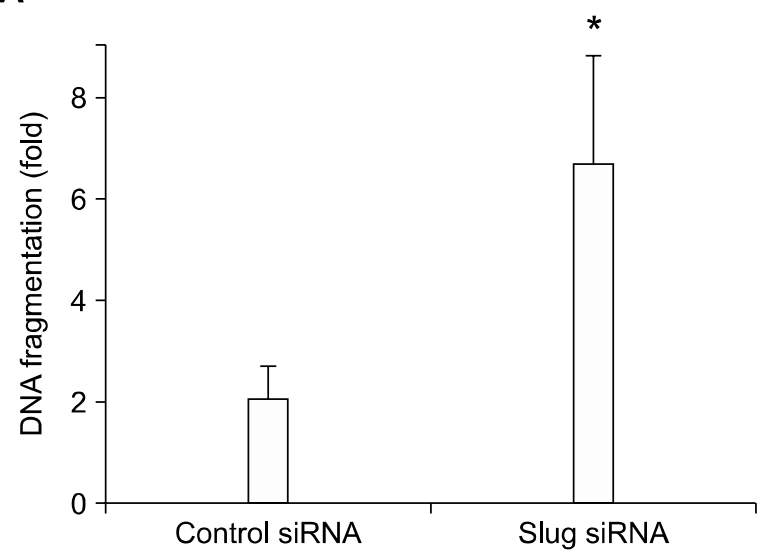

B

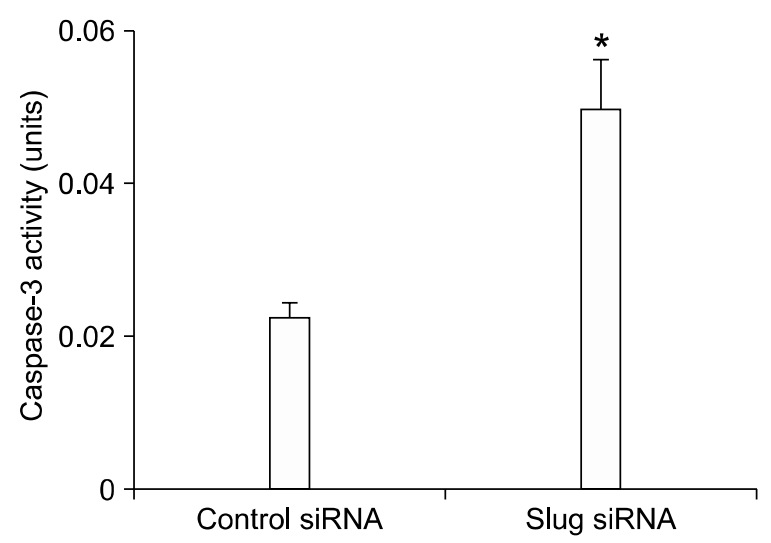

Figure 5. Slug knockdown enhances $\mathrm{H}_{2} \mathrm{O}_{2}$-induced FLS apoptosis and caspase-3 activation. (A) RA FLS $(n=5)$ were transfected with control or Slug siRNA for 3 days and then stimulated with medium or $0.5 \mathrm{mM} \mathrm{H}_{2} \mathrm{O}_{2}$. After $6 \mathrm{~h}$, DNA fragmentation was measured by ELISA. The magnitude of induction of DNA fragmentation in $\mathrm{H}_{2} \mathrm{O}_{2}$-treated $\mathrm{FLS}$ is shown relative to control value (medium-treated $\mathrm{FLS}$ ). ${ }^{*} P<0.05$ compared with control siRNA-transfected cells. (B) RA FLS $(n=3)$ transfected with control or Slug siRNA were treated with $0.5 \mathrm{mM} \mathrm{H}_{2} \mathrm{O}_{2}$ for $6 \mathrm{~h}$. Caspase-3 activity was measured using ApoAlert Caspase-3 assay. ${ }^{*} P<0.05$ compared with control siRNA-transfected cells.

transactivation or activate $\mathrm{p} 21$ pathway, resulting in cell-cycle arrest and DNA repair (Vousden and Lu, 2002). However, how this critical step is differentially regulated in specific cell types remains largely unknown. In FLS, overexpression of p53 did not induce apoptosis via Puma transactivation, but induced p21 (Cha et al., 2006), and the mechanism for this selective transactivation of downstream molecules could not be explained. Slug was proposed to regulate the activation of p53 downstream molecules in hematopoietic progenitor cells. Once activated by DNA damage, p53 induces molecules including Puma and Slug. Slug then shifts the fate of damaged myeloid progenitor cells toward arrest and survival by selectively repressing Puma gene transactivation (Wu et al., 2005; Zilfou et al., 2005). Our present findings also demonstrate that Slug is involved in Puma gene regulation. Puma transactivation by $\mathrm{H}_{2} \mathrm{O}_{2}$ was minimal in control FLS, and this was compatible with the previous findings (Cha et al., 2006). On the other hand, we found that when Slug was knocked-down by RNA interference, Puma gene transactivation was significantly increased by $\mathrm{H}_{2} \mathrm{O}_{2}$ stimulation. Without $\mathrm{H}_{2} \mathrm{O}_{2}$ treatment, Puma induction by Slug knock-down was minimal, which suggests that influence of Slug on Puma expression is restricted on the condition of the presence of extracellular apoptotic stimuli such as $\mathrm{H}_{2} \mathrm{O}_{2}$. Contrary to previous findings, however, Slug was not induced by $\mathrm{p} 53$ in FLS in our study. Exogenous overexpression of p53 did not increase transcriptional activation of Slug in FLS, and this finding was discordant with the results observed in hematopoietic progenitor cells as mentioned above (Wu et al., 2005). These results imply that, in FLS, S/ug can be induced by genotoxic stimuli such as $\mathrm{H}_{2} \mathrm{O}_{2}$ via p53-independent mechanism, which then leads to the suppression of proapoptotic gene transcription.

Although Slug has been observed to be induced by $\mathrm{p} 53$ in hematopoietic stem cells, this finding has not been reproduced in other cell types. In early vertebrate mesoderm, Slug was reported to be induced by NF-kB, which, in turn, was activated by Bcl-xL (Zhang et al., 2006). Slug was induced by stem cell factor/c-Kit pathway in multidrug-resistant malignant mesothelioma cells (Catalano et al., 2004). Ultraviolet radiation-induced Slug elevation in keratinocytes was mediated, at least in part, through the ERK and p38 MAPK cascades (Hudson et al., 2007). The mechanism in which Slug is induced by $\mathrm{H}_{2} \mathrm{O}_{2}$ in FLS remains to be illuminated in the future, but p53 does not seem to be an important mediator from our result. Despite the fact that $\mathrm{p} 53$ has been reported to be overexpressed in RA synovium, the role of p53 in RA FLS still remains uncertain. In fact, p53 may not play an important role in FLS apoptosis. Adenoviral gene transfer of p53 did not induce apoptosis of FLS (Cha et al., 2006). A recent study indicated that p53 not only was found to be important in inducing Puma in nucleus, but also was found to be necessary in cytoplasm to mediate the downstream apoptotic effect of Puma (Chipuk et al., 2005). However, in FLS, p53 was not required in Puma-mediated apoptosis (You et al., 2006). Puma efficiently induced apoptosis in both control and p53-deficient FLS (You et al., 2006). Furthermore, adenoviral gene transfer of Puma caused massive apoptosis of malignant 
glioma cells regardless of p53 status (Ito et al., 2005). These inconsistent findings imply that apoptosis regulating molecules including p53, Slug, and Puma may be interacting differentially according to tissue-specific cell types. The FLS-specific apoptotic pathway needs to be elucidated in order to establish apoptosis as a therapeutic target in RA.

In conclusion, the present study demonstrated that Slug was expressed and induced by genotoxic stimuli in RA FLS. Suppression of Slug augmented $\mathrm{H}_{2} \mathrm{O}_{2}$-induced Puma gene transactivation and facilitated apoptosis of FLS. Slug may therefore represent a novel therapeutic target in RA.

\section{Methods}

\section{ST samples and primary synoviocytes culture}

The experimental protocol was approved by the local ethics committee and a signed consent form was obtained from each patient. ST samples were obtained from patients with osteoarthritis and RA at the time of joint replacement. Patients with RA were diagnosed according to the standards of the American College of Rheumatology (Arnett et al., 1988). The ST samples were either processed for cell culture or snap frozen and stored at $-80^{\circ} \mathrm{C}$. ST was minced, digested overnight with $5 \mathrm{mg} / \mathrm{ml}$ type IV collagenase (Sigma, St. Louis, MO) and $150 \mu \mathrm{g} / \mathrm{ml}$ type I DNase (Sigma), and separated from undigested tissue by unit gravity sedimentation. After collecting the suspended cells into fresh tubes, the cells were harvested by centrifugation at $500 \times g$ for $10 \mathrm{~min}$. The pellet was washed twice with DMEM (Life Technologies, NY) containing $10 \%$ FCS. Resuspended cells were plated at a concentration of $2 \times 10^{6} / \mathrm{ml}$ in a total volume of $1 \mathrm{ml} / 200$ $\mathrm{mm}^{2}$ into T-25 culture flasks. After overnight incubation, non-adherent cells were removed by replacing fresh culture medium, and attached cells were cultured in DMEM with $10 \%$ FCS and 50 units $/ \mathrm{ml}$ penicillin, $50 \mu \mathrm{g} / \mathrm{ml}$ streptomycin, and $0.025 \mu \mathrm{g} / \mathrm{ml}$ amphotericin B until $90 \%$ confluent growth. Primary cultured cells were passaged three to four times over several weeks for subsequent experiments.

\section{RNA isolation and RT-PCR}

Total RNA was isolated from ST or cultured FLS using TRIZOL reagent that contained phenol and guanidine isothionate in a monophase solution following the manufacturer's recommendations (Invitrogen Carlsbad, CA). 1 $\mu \mathrm{g}$ of pooled RNA was reverse transcribed in a total reaction volume of $20 \mu \mathrm{l}$ containing $0.5 \mu \mathrm{g}$ random hexamer primer, 20 units RNasin ${ }^{\circledR}$ ribonuclease inhibitor and superscript ${ }^{\mathrm{TM}}$ II reverse transcriptase (Invitrogen, CA). The PCR amplification of the CDNA aliquots was performed by adding $2.5 \mathrm{mM}$ deoxyribonucleoside triphosphate (dNTPs), $2.5 \cup$ Taq DNA polymerase (Boehringer Mannheim, Germany) and $0.25 \mu \mathrm{M}$ each of the sense and anti-sense primers. The following sense and anti-sense primers for Slug and $\beta$-actin were used (all written in $5^{\prime} \rightarrow 3^{\prime}$ direction): Slug sense TCCTCCATCTGACACCTCCTC, anti-sense CCCCCGTGTGAGTTCTAATGT; $\beta$-actin sense TACGTTGCTATCCAGGCTGTG, anti-sense AGTACTTGCGCTCAGGAGGAG. The levels of Slug, Puma, and $\beta$-actin mRNA expression were measured by real-time RT-PCR using an ABI PRISM 7000 sequence detector system (Applied Biosystems, Foster City, CA). The real-time RT-PCR amplification was performed using the pre-developed Assay-on-demand gene expression set for Slug gene (Assay ID Hs00161904_m1, Gene bank accession number NM_003068, Applied Biosystems), Puma gene (Assay ID Hs00248075_m1, Gene bank accession number NM_014417, Applied Biosystems) and human ACTB ( $\beta$-actin) for the endogenous control (VIC/MGB Probe, Applied Biosystems) in combination with the TaqMan ${ }^{\mathbb{R}}$ Universal PCR Master Mix. Quantitation of Slug and Puma mRNA expression was calculated using the absolute method provided by the manufacturer (Applied Biosystems). Analysis was performed using the ABI PRIMS 7000 Sequence Detection software (Applied Biosystems, Foster City, CA). The expression level of selected genes in unknown samples was calculated as ratio of selected gene mRNA versus $\beta$-actin. Quantitation of selected gene mRNA and $\beta$-actin were performed using a standard curves made from known serial dilution of rheumatoid FLS. A negative control without template was included in each experiment.

\section{Synoviocytes transfections}

Recombinant adenovirus expressing human wild-type $p 53$ gene (Ad-p53) and recombinant adenovirus expressing green fluorescent protein (Ad-GFP) were purchased from VECTOR BIOLABS (Philadelphia,PA). Cells cultured in DMEM supplemented with $1 \%$ FCS for $24 \mathrm{~h}$ were infected with Ad-p53 or Ad-GFP at an approximate multiplicity of infection of 100 for $24 \mathrm{~h}$. Small interference RNA (siRNA) for Slug and control siRNA were purchased from Dharmacon (Lafayette, CO). Transient transfection of FLS was performed using the Amaxa Human Dermal Fibroblast Nucleofector $^{\mathrm{TM}}$ kit (NHDF-adult; Amaxa Biosystems, Gaithersburg, MD), according to the manufacturer's protocols. Briefly, siRNA $(1 \mu \mathrm{g})$ was added to $5 \times 10^{5} \mathrm{FLS}$ suspended in $100 \mu \mathrm{l}$ of Nucleofector ${ }^{\mathrm{TM}}$ solution. The mixture was then transferred into the electroporation cuvette and subjected to electroporation using the U-23 program, according to the manufacturer's instructions. Immediately after electroporation, the cells were suspended in $500 \mu \mathrm{l}$ of cell culture medium, and transferred into culture dishes or plates. The transfected cells were then grown until the knocked-down effect of Slug siRNA was evident by RT-PCR.

\section{Western blot analysis}

Whole cell lysates (WCL) were prepared using RIPA buffer that contained $50 \mathrm{mM}$ Tris- $\mathrm{Cl}$ (pH 8.0), $150 \mathrm{mM} \mathrm{NaCl}, 1 \%$ NP40, $0.1 \%$ SDS, and $10 \mathrm{mM}$ sodium deoxycholate. The concentration of WCL was determined using a Bio-RAD protein assay kit (Bio-Rad, Richmond, CA). Next, $15 \mu \mathrm{l}$ of WCL were separated by electrophoresis on a $10 \%$ acrylamide gel using a constant voltage of $80 \mathrm{~V}$ for $2 \mathrm{~h}$. 
The separated proteins were transferred electrophoretically onto nitrocellulose membranes that had been preblocked for $4 \mathrm{~h}$ at room temperature in TTBS $(20 \mathrm{mM}$ Tris- $\mathrm{Cl}, \mathrm{pH} 8.0,500 \mathrm{mM} \mathrm{NaCl}, 0.05 \%$ (v/v) Tween-20) containing $1 \%$ skim milk powder. The membranes were incubated overnight at $4^{\circ} \mathrm{C}$ with 1:1000-diluted antibodies to p53 (mouse monoclonal anti-p53 antibody, Santacruz, $\mathrm{CA}$ ) and $\beta$-actin (mouse monoclonal anti- $\beta$-actin antibody, Sigma, St. Louis, MO) in TTBS. The membranes were washed with TTBS three times for $15 \mathrm{~min}$, and then incubated for $1 \mathrm{~h}$ with horseradish peroxidase-conjugated anti-mouse IgG or anti-rabbit antibody (1:5000, Jackson Immunoresearch, West Grove, PA). Proteins were detected using an $\mathrm{ECL}^{\mathrm{TM}}$ Western blot detection system (Amersham Life Science, Buckinghamshire, UK).

\section{Cell viability and apoptosis assays}

Three days after siRNA transfection, FLS were stimulated with $0.5 \mathrm{mM} \mathrm{H}_{2} \mathrm{O}_{2}$ for $9 \mathrm{~h}$. Both nonadherent and adherent FLS were suspended in $0.4 \%$ trypan blue in PBS $(\mathrm{pH} 7.4)$, and counted using Hemacytometer (Horsham, PA). The cells that excluded the blue dye and had a well-defined cellular outline were scored as live. Total number of live cells was calculated and averaged over at least three times. FLS transfected with siRNA were plated in 96-well plastic plates $\left(2 \times 10^{4}\right.$ cells/well) and incubated with media or $0.5 \mathrm{mM} \mathrm{H}_{2} \mathrm{O}_{2}$ for $6 \mathrm{~h}$. After incubation, apoptosis was determined using a Cell Death Detection ELISA ${ }^{\text {PLUS }}$ kit (Roche, Mannheim, Germany) according to the manufacturer's instruction. It is based on a quantitative sandwich-enzyme immunoassay using mouse monoclonal antibodies against DNA and histones that allow for the specific, quantitative determination of cytoplasmic histone-associated DNA fragments (mono- and oligonucleosomes). Each measurement was done in duplicate, and the results are presented as the fold induction compared with control samples (media-treated cells).

\section{Caspase-3 activation assay}

FLS transfected with control or Slug siRNA were plated in six-well plastic plates $\left(2 \times 10^{5}\right.$ cells/well $)$ and incubated with media or $0.5 \mathrm{mM} \mathrm{H}_{2} \mathrm{O}_{2}$ for $6 \mathrm{~h}$. Caspase- 3 activation was measured using the ApoAlert Caspase-3 Colorimetric Assay kit (Clontech, CA, US) according to the manufacturer's instructions.

\section{Statistical analysis}

Data are expressed as mean \pm SEM. The statistical significance of experimental results was calculated by paired Student's $t$-test or Mann-Whitney $U$-test. $P$ values less than 0.05 were considered significant.

\section{Acknowledgements}

This research was supported by the Samsung Biomedical Research Institute grant, \#SBRI C-A7-224 and by Basic Research Program through the National Research Foundation of Korea (NRF) funded by the Ministry of Education, Science and Technology (2009-0073632).

\section{References}

Arnett FC, Edworthy SM, Bloch DA, McShane DJ, Fries JF, Cooper NS, Healey LA, Kaplan SR, Liang MH, Luthra HS, et al. The American Rheumatism Association 1987 revised criteria for the classification of rheumatoid arthritis. Arthritis Rheum 1988;31:315-24

Byun HS, Won M, Park KA, Kim YR, Choi BL, Lee H, Hong JH, Piao L, Park J, Kim JM, et al. Prevention of TNF-induced necrotic cell death by rottlerin through a Nox1 NADPH oxidase. Exp Mol Med 2008;40:186-95

Catalano A, Rodilossi S, Rippo MR, Caprari P, Procopio A. Induction of stem cell factor/c-Kit/slug signal transduction in multidrug-resistant malignant mesothelioma cells. J Biol Chem 2004;279:46706-14

Ceponis A, Hietanen J, Tamulaitiene M, Partsch G, Patiala $\mathrm{H}$, Konttinen YT. A comparative quantitative morphometric study of cell apoptosis in synovial membranes in psoriatic, reactive and rheumatoid arthritis. Rheumatology (Oxford) 1999;38:431-40

Cha HS, Rosengren S, Boyle DL, Firestein GS. PUMA regulation and proapoptotic effects in fibroblast-like synoviocytes. Arthritis Rheum 2006;54:587-92

Chipuk JE, Bouchier-Hayes L, Kuwana T, Newmeyer DD, Green DR. PUMA couples the nuclear and cytoplasmic proapoptotic function of p53. Science 2005;309:1732-5

Fei P, Bernhard EJ, El-Deiry WS. Tissue-specific induction of p53 targets in vivo. Cancer Res 2002;62:7316-27

Firestein GS. Evolving concepts of rheumatoid arthritis. Nature 2003;423:356-61

Firestein GS, Yeo M, Zvaifler NJ. Apoptosis in rheumatoid arthritis synovium. J Clin Invest 1995;96:1631-8

Gupta PB, Kuperwasser C, Brunet JP, Ramaswamy S, Kuo WL, Gray JW, Naber SP, Weinberg RA. The melanocyte differentiation program predisposes to metastasis after neoplastic transformation. Nat Genet 2005;37:1047-54

Han J, Flemington C, Houghton AB, Gu Z, Zambetti GP, Lutz $\mathrm{RJ}$, Zhu L, Chittenden T. Expression of bbc3, a pro-apoptotic $\mathrm{BH} 3-$ only gene, is regulated by diverse cell death and survival signals. Proc Natl Acad Sci USA 2001;98:11318-23

Hemavathy K, Ashraf SI, Ip YT. Snail/slug family of repressors: slowly going into the fast lane of development and cancer. Gene 2000;257:1-12

Hudson LG, Choi C, Newkirk KM, Parkhani J, Cooper KL, Lu $P$, Kusewitt DF. Ultraviolet radiation stimulates expression of Snail family transcription factors in keratinocytes. Mol Carcinog 2007;46:257-68

Ito H, Kanzawa T, Miyoshi T, Hirohata S, Kyo S, Iwamaru A, Aoki $\mathrm{H}$, Kondo $\mathrm{Y}$, Kondo S. Therapeutic efficacy of PUMA for malignant glioma cells regardless of p53 status. Hum Gene Ther 2005;16:685-98

Kajita M, McClinic KN, Wade PA. Aberrant expression of the transcription factors snail and slug alters the response to genotoxic stress. Mol Cell Biol 2004;24:7559-66

Kurrey NK, K A, Bapat SA. Snail and Slug are major 
determinants of ovarian cancer invasiveness at the transcription level. Gynecol Oncol 2005;97:155-65

Martin TA, Goyal A, Watkins G, Jiang WG. Expression of the transcription factors snail, slug, and twist and their clinical significance in human breast cancer. Ann Surg Oncol 2005;12:488-96

Matsumoto S, Muller-Ladner U, Gay RE, Nishioka K, Gay S. Ultrastructural demonstration of apoptosis, Fas and Bcl-2 expression of rheumatoid synovial fibroblasts. J Rheumatol 1996;23:1345-52

Nakajima T, Aono H, Hasunuma T, Yamamoto K, Shirai T, Hirohata K, Nishioka K. Apoptosis and functional Fas antigen in rheumatoid arthritis synoviocytes. Arthritis Rheum 1995;38:485-91

Nakano K, Vousden KH. PUMA, a novel proapoptotic gene, is induced by p53. Mol Cell 2001;7:683-94

Perez-Mancera PA, Gonzalez-Herrero I, Perez-Caro M, Gutierrez-Cianca N, Flores T, Gutierrez-Adan A, Pintado B, Sanchez-Martin M, Sanchez-Garcia I. SLUG in cancer development. Oncogene 2005;24:3073-82

Sugiyama M, Tsukazaki T, Yonekura A, Matsuzaki S, Yamashita S, Iwasaki K. Localisation of apoptosis and expression of apoptosis related proteins in the synovium of patients with rheumatoid arthritis. Ann Rheum Dis 1996; $55: 442-9$

Tak PP, Zvaifler NJ, Green DR, Firestein GS. Rheumatoid arthritis and p53: how oxidative stress might alter the course of inflammatory diseases. Immunol Today 2000;21:78-82

Vitali R, Mancini C, Cesi V, Tanno B, Mancuso M, Bossi G, Zhang Y, Martinez RV, Calabretta B, Dominici C, Raschella G. Slug (SNAI2) down-regulation by RNA interference facilitates apoptosis and inhibits invasive growth in neuroblastoma preclinical models. Clin Cancer Res 2008; 14:4622-30

Vousden KH, Lu X. Live or let die: the cell's response to p53. Nat Rev Cancer 2002;2:594-604

Wu WS, Heinrichs S, Xu D, Garrison SP, Zambetti GP, Adams JM, Look AT. Slug antagonizes p53-mediated apoptosis of hematopoietic progenitors by repressing puma. Cell 2005; 123:641-53

You X, Boyle DL, Hammaker D, Firestein GS. PUMA-mediated apoptosis in fibroblast-like synoviocytes does not require p53. Arthritis Res Ther 2006;8:R157

Yu J, Zhang L, Hwang PM, Kinzler KW, Vogelstein B. PUMA induces the rapid apoptosis of colorectal cancer cells. Mol Cell 2001;7:673-82

Yu J, Wang Z, Kinzler KW, Vogelstein B, Zhang L. PUMA mediates the apoptotic response to p53 in colorectal cancer cells. Proc Natl Acad Sci USA 2003;100:1931-6

Zhang C, Carl TF, Trudeau ED, Simmet T, Klymkowsky MW. An NF-kappaB and slug regulatory loop active in early vertebrate mesoderm. PLoS ONE 2006;1:e106

Zilfou JT, Spector MS, Lowe SW. Slugging it out: fine tuning the p53-PUMA death connection. Cell 2005;123:545-8 